\title{
Participatory Varietal Selection and Agronomic Performance Evaluation of Common Bean (Phaseolus vulgaris L.) Genotypes in MetekelZone, North Western Part of Ethiopia
}

\author{
Zelalem Zewdu* \\ Fogera National Rice Research and Training Center, Ethiopia
}

*Corresponding Authors: Zelalem Zewdu, Fogera National Rice Research and Training Center, Ethiopia.

\begin{abstract}
Participatory variety selection of common bean (Phaseolus vulgaris L.) genotypes was conducted during 2013 main cropping season in Dibate district North western part of Ethiopia.The experiment was conducted to evaluate and recommend high yielding early maturing common bean genotypes through participatory variety selection and to assess farmers selection criteria for improved common bean varieties for future common bean breeding program. Four common bean genotypes which were replicated over four farmers' fields were evaluatedin this study. The analysis of variance revealed a highly significant difference $(p \leq 0.001)$ for days to maturity and plant height, while a significant difference ( $p \leq 0.01)$ was observed for grain yield among the tested genotypes. Both male and female group of farmers had set almost similar selection criteria and were notdirectly targeting the yield only rather than selecting the yield contributing traits also. Both male and female farmers preferred the red color beans for their local dish preparation as boiled bean" Nifro" and "Shiro". Genotype SER-119 followed by SER-118 which are red in color were the leading in both female and male group selection criteria and in their agronomic performance like grain yield, number of pods per plant, number of seeds per pod and number of seeds per plant.As a result, these two genotypes are recommendedfor production in the tested areas and similar agroecological Zone of Metekeland the bean breeding program should consider the farmers criteria especially for local consumption as a target trait.
\end{abstract}

Keywords: Common bean,Phaseolus vulgaris, grain yield, PVS

\section{INTRODUCTION}

Common bean (Phaseolus vulgaris L.) is the most commonly consumed legume worldwide, and source of protein for small scale farmers and cash crop in many lowlands and mid-altitude areas (Porch et al., 2013). According to CSA, (2019), common bean takes $12.73 \%$ of the total area coverage $(1,620,497.30$ hectares) and $9.54 \%$ (about 30,113,480.57 quintals) of the produced grain in Ethiopia.Ethiopia had got $85 \%$ of export estimated earnings from pulses, exceeding that of other pulses such as lentils, faba bean and chickpea (Rahmeto, 2017). According to GAIN, (2018), Ethiopia exported $14 \%$ (340,000 metric tons) of pulse production and generated \$ 255 million US dollars.

Common bean can grow in a wide range of agroecologyof Ethiopia up to 600 meter above sea level which causes poor pod setting and a doesn't take long time to mature (Habte et al., 2014). Bean can be produced either as sole crop or intercrop with cereals like maize and sorghum. This helps not only securing yield but also has the advantages of restoring soil fertility. Even though, the country has huge potentialand the crop has tremendous advantages, theproduction and productivity has been challenging by low adoptionof improved technologies, drought, and lack of improved varieties, poor culturalpractices, disease, and environmental degradation (Legese,2004;Rahmeto, 2017).

In addition to the above-mentioned constraints, low adoption and access to improved common bean varieties to specific growing conditionsare the serious problems on the expansion of production and productivity of the crop (Amanuel A., et al., 2018). For this low adoption of the technologies, poor linkage of stakeholders with the breeding program take great share. Involvement of farmers before releasing a variety would facilitate the adoption and acceptanceby creating awareness of the technology. This enables farmers to decide and choose which variety fits their interest(Yasin G., 2017). 
Participatory Variety Selection (PVS)has been found very effective in addressing many of these problems mentioned above in different crops breeding program. PVS could be very useful to identify farmers-acceptedvarieties and thereby overcome the constraints that insist farmers to grow land races and old varieties (Tadesse et al., 2014; Semagnet al., 2017).Therefore, the study was conducted with the objectives to evaluate and recommend high yielding early maturing common bean varieties through participatory variety selection and to assess farmers selection criteria for improved common bean varietiesand include in the future bean breeding program.

\section{MATERIAL AND MethodS}

A field experiment was conducted at Dibate district of Benishangul Gumuz regional state $\left(10^{0} 39^{\prime} \mathrm{N}\right.$ and $36^{0} 13$ E) Ethiopia, at 1438 meter above sea level, during 2013 main cropping season. The location of the experimental area is located in Figure1 below.

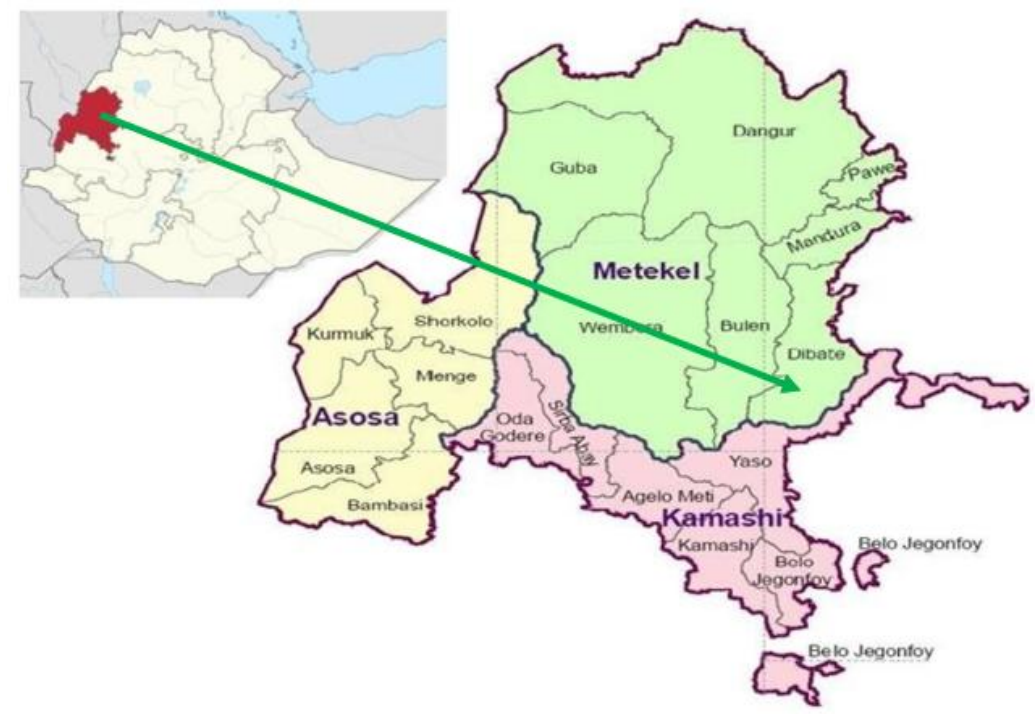

Figure1. Geographical map of the study area

Four common bean genotypes (three recently advanced and good performing genotypes for the area and one released variety) were planted in a randomized complete block design with four replications. The trail was replicated on four farmers field.Each genotype was planted in a plot size of $10 \mathrm{~m}$ by 10 m. A spacing of $40 \mathrm{~cm}$ between rows and $10 \mathrm{~cm}$ between plants were used. A seed rate of $100 \mathrm{~kg} / \mathrm{ha}$ and fertilizer rate of $100 \mathrm{~kg}$ P205and $100 \mathrm{~kg}$ urea fertilizers were used respectively. All other agronomic practices were done accordingly.

\section{DATA COLLECTION AND ANALYSIS}

Agronomic data were collected on five randomly selected plants from the middle rows for plant height, number of pods per plant, number of seeds per pod, number of seeds pe plant while a plotbased data was taken for days to maturity. Hundred seed weight and grain yield wererecodedafter harvest from the middle rows. The visual evaluation and selection of the varieties by farmer was done when the crop reaches to physiological maturity stage by involving 10 female and 10 male common bean producing farmers. The farmers were selected in collaboration with Kebele developmental agents. A clear briefing was given for the farmers and then grouped separately (male group and female group) and discussed on the common bean variety selection criteria. After the two groups set their variety selection criteria, they gave scores for each selection criteria as $(1=$ Very good, $2=$ Good, $3=$ Medium, 4= Poor, 5= Very Poor). Genstat software (VSN International, 2012) was used to analyze 
Participatory Varietal Selection and Agronomic Performance Evaluation of Common Bean (Phaseolus vulgaris L.) Genotypes in MetekelZone, North Western Part of Ethiopia

the agronomic data with the following linear equation. The linear model used for the analysis was as follows:

$\mathrm{y}_{\mathrm{ij}}=\mu+\mathrm{g}_{i}+\mathrm{r}_{j}+\mathrm{e}_{\mathrm{ij}}$

Where,$\mu=$ Overall mean,

Yij = phenotypic observation in the $\mathrm{i}^{\text {th }}$ treatment and $\mathrm{j}^{\text {th }}$ replication,

$\mathrm{gi}=$ effect of $\mathrm{i}^{\text {th }}$ treatment,

$r j=e f f e c t$ of $j^{\text {th }}$ replication,

eij $=$ Random error associated with $\mathrm{i}^{\text {th }}$ treatment and $\mathrm{j}^{\text {th }}$ replication .

Table1. Description of experimental materials used for the study

\begin{tabular}{|l|l|l|}
\hline Genotypes & Seed color & Source \\
\hline SER-119 & Red & MARC \\
\hline SER-118 & Red & MARC \\
\hline Nassir & Red & MARC \\
\hline ICN Bunsi x S x B 405 & Red & MARC \\
\hline
\end{tabular}

Note: - MARC = Melkasa Agricultural Research Center

\section{RESUlT AND DISCUSSION}

The analysis of variance revealed a highly significant difference $(\mathrm{p} \leq 0.001)$ among genotypes for days to maturity and plant height while a significant difference $(\mathrm{p} \leq 0.01)$ was recorded for grain yield and seed per pods $(p \leq 0.05)$. On the other hand, seeds per plant and hundred seed weight were nonsignificant for the tested genotypesa

s presented in Table 2. This result is in line with the findings of different scholars. Teame G. et al., (2016), Misgana M.and Tadesse M. (2017)and Simon Y. et al., (2020) had also reported that common bean genotypes exhibited a significant variation for yield and yield related traits like plant height, number of nodes, biological yield, pods per plant, harvest index and hundred seed weight.

The average days to maturity ranged from 75 to 94 days; the variety Nassir matured earliest than the others while ICN Bunsi x S x B 405 was matured late.Simon Y. et al.,(2020)had also found that variety Nasir was the earliest genotype for days to flowering among the tested genotypes. The average plant height was ranged from $35 \mathrm{~cm}$ to $73.8 \mathrm{~cm}$; Nassir has the shortest plant height and ICN Bunsi x S x B 405 had the longest height. High number of pods per plant was recorded on genotypes SER-119 (10.6) followed by Ser -118 (8.9) respectively. On the other hand, genotypes had responded differently for seeds per pod, seeds per plant, hundred seed weight and grain yield. As a result,among the tested genotypes, SER-119 was the best adopted genotype followed by SER-118 for number of pods per plant (10.6), number of seeds per pod (5.3), number of seeds per plant (42.7), hundred seed weight (17.5 gm) and grain yield (1794.4 kg/ha). Alemayeh B., (2014) and Netra et al., (2019), had also reported a high genetic variability among the tested common bean genotypes for days to flowering, days to maturity, pods per plant, seeds per pod and hundred seed weight among twenty bush type genotypes. Addisuet al., (2018) had also reported that a highly significant difference $(\mathrm{P}<0.01)$ for seed per pod, 100 seed weight and grain yieldamong the twelve released genotypes.

Table2. Mean grain yield and yield components of fourcommon bean genotypes evaluated in 2013 cropping seasons in North part of Ethiopia

\begin{tabular}{|l|c|c|c|c|c|c|c|}
\hline \multicolumn{1}{|c|}{ Genotypes } & Dma & Pht & Poplt & Sppo & Spplt & Hswt & GY \\
\hline SER-119 & 88 & 35.0 & 10.6 & 5.3 & 42.7 & 17.5 & 1794.4 \\
\hline SER -118 & 85 & 36.3 & 8.9 & 4.7 & 31.2 & 16.8 & 1616.2 \\
\hline
\end{tabular}


Participatory Varietal Selection and Agronomic Performance Evaluation of Common Bean (Phaseolus vulgaris L.) Genotypes in MetekelZone, North Western Part of Ethiopia

\begin{tabular}{|c|c|c|c|c|c|c|c|}
\hline ICN Bunsi x S x B 405 & 94 & 73.8 & 8.8 & 5.1 & 32.8 & 15.5 & 1229.4 \\
\hline Nassir & 75 & 63.7 & 7.8 & 5.3 & 30.4 & 17.3 & 1498.8 \\
\hline Mean & 85 & 52.2 & 9.0 & 5.1 & 34.3 & 16.8 & 1534.7 \\
\hline $\mathrm{CV}$ & 2.7 & 14.2 & 22.9 & 6.2 & 22.2 & 17.7 & 15.0 \\
\hline LSD & 3.694 & 11.9 & 3.3 & 0.5 & 12.1 & 4.8 & 355.2 \\
\hline Sign $(5 \%)$ & $* * *$ & $* * *$ & NS & $*$ & NS & NS & $* *$ \\
\hline
\end{tabular}

Dma $=$ Number of days to maturity, Hswt $=100$ seed weight $(\mathrm{gm})$, Pht $=$ Plant height, Poplt $=$ Number of pods per plant, Spplt= Number of seed per plant, Sppo= Number of seed per pod, Grain yield $(\mathrm{kg} / \mathrm{ha})$

The visual observation and selection of common bean genotypes were done for female and male groups independently as presented in Table 3 and Table 4 . The female farmers selected grain yield, number of seeds per pod, number of pods per plant, branching habit and seed coloras a criterion for common bean variety selection. Whereas the male group were used grain yield, number of pods per plant, seeds per pod, disease resistance. Theabove listed criteria were ranked according to their level of importance in both groups. From both groups the primary selection criteria was grain yield. The farmers criteria were also the targets of the researcher for better variety selection. This indicates that the research targets the traits that the client needs.

Table3. Female farmers' variety selection criteria, scores and ranks of four common bean genotypes in Dibate district

\begin{tabular}{|l|l|l|l|l|l|l|l|l|}
\hline Genotypes & $\begin{array}{l}\text { Grain } \\
\text { yield }\end{array}$ & Seeds/pod & $\begin{array}{l}\text { Pods / } \\
\text { plant }\end{array}$ & $\begin{array}{l}\text { Branching } \\
\text { habit }\end{array}$ & $\begin{array}{l}\text { Seed } \\
\text { color }\end{array}$ & Total & Average & Rank \\
\hline SER-119 & 1 & 1 & 3 & 1 & 1 & 7 & 1.4 & 1 \\
\hline SER -118 & 1 & 3 & 2 & 1 & 3 & 10 & 2 & 2 \\
\hline Nassir & 2 & 3 & 3 & 1 & 2 & 11 & 2.2 & 3 \\
\hline ICN Bunsi x S x B 405 & 2 & 2 & 3 & 3 & 3 & 13 & 2.6 & 4 \\
\hline
\end{tabular}

As it is stated by Gemechuet al., (2002) researchers and farmers have their own unique and common experience, which should be effectively exploited in the research process. This is an indication that clients and researchers should complement each other on variety development and helps for the rapid adoption of the variety in the development system. From the two groups varieties were ranked in similar manner that SER-119 was selected as preferred genotypes followed by SER-118, Nassir and ICN Bunsi x S x B 405. This indicated that farmers had came with the similar evaluation and level of understanding from both groups and would help to asses the understanding of different groups of farmers and will direct the future expansion of the technology in the target areas and similar areas. A similar study was conducted usingat Hawassa zuria, Meskan and East Badawacho districts of SNNPR in 2013 cropping season and found that SER-119 was the leading among the tested genotypes and selected by farmers. As a result, it was recommended for further scaling up for the tested and similar agroecology.

Table4. Male farmers' variety selection criteria, scores and ranks of four common bean genotypes in Dibate district

\begin{tabular}{|l|l|l|l|l|l|l|l|}
\hline Genotypes & $\begin{array}{l}\text { Grain } \\
\text { yield }\end{array}$ & $\begin{array}{l}\text { Pods/ } \\
\text { plant }\end{array}$ & Seeds/pod & $\begin{array}{l}\text { Disease } \\
\text { resistance }\end{array}$ & Total & Average & Rank \\
\hline SER-119 & 1 & 1 & 1 & 1 & 4 & 0.8 & 1 \\
\hline SER -118 & 2 & 1 & 1 & 1 & 5 & 1.0 & 2 \\
\hline Nassir & 2 & 1 & 3 & 1 & 7 & 1.4 & 3 \\
\hline ICN Bunsi x S x B 405 & 3 & 2 & 2 & 1 & 8 & 1.6 & 4 \\
\hline
\end{tabular}

\section{CONCLUSION AND RECOMMENDATION}

Participatory variety selection is a better option to create a common understanding between researchers and different clients by consideringtraits that meet their interest.This makes the breeding program more successful and users can easily adopt the technology after release.In this study, male and female group of farmers had set grain yield, pods per plant, seeds per pod and resistance to different disease as primary selection criteria for common bean. In addition to this the female group 
had also included grain color and branching habit in their selection criteria. Female farmers preferred the red color beans for their local consumptions as boiled bean" Nifro" and "Shiro".

Genotype SER-119 followed by SER-118 which are red in color were the primary choice of both female and male group of farmers and good in their agronomic performance like grain yield, number of pods per plant, number of seeds per pod and number of seeds per plant. As a result, genotype SER119 and SER-118 are recommended and used for production in the tested areas and similar agroecological Zone of Metekel. Bean research program should consider the farmers criteria especially color for local consumption in the tested area as a target trait in the future breeding program

\section{ACKNOWLEDGMENT}

The author is highly acknowledged Ethiopian institute of Agricultural Research for the financial support through Pawe Agricultural Research Center and Melkasa lowland pulse research program for giving the genotypes for evaluation.

\section{REFERENCES}

[1] Addisu T., Goshime M., Mesele H., Alemayehu Z., 2018. Evaluations and selection of improved common bean (Phaseulus vulgaris L.) varieties at SNNPR - Ethiopia. Journal of Natural Sciences Research. ISSN 2225-0921, Vol.8, No.13, 2018

[2] Alemayehu B., 2014. Genetic variation for grain yield of common bean (Phaseolus vulgaris L.) in sole and maize/bean intercropping system. Asian journal of crop $\quad$ science. ISSN $1994-7879$. DOI: 10.3923/ajcs.2014.158.164.

[3] Amanuel A., and Girma A., 2018. Production Status, Adoption of Improved Common Bean (Phaseolus vulgaris L.) Varieties and Associated Agronomic Practices in Ethiopia. Journal of Plant Science \& Research. Volume 5, Issue 1 - 2018

[4] CSA (Central Statistics Agency) of Ethiopia, 2019. Report on Area and production of major crops. Volume I.

[5] Evaluation of Common Bean (Phaseolus vulgaris L.), 2020. Genotypes for yield and related traits at Areka, Southern Ethiopia. Advances in Agriculture Volume

[6] GAIN (Global Agricultural Information Network),2018. Pulse crops market update. GANIN report no. ET1819. FASAddis Ababa.

[7] Gemechu K., Yohannes G., Kiflu B., Chilot Y. and Asgelil D.,2002. Towards farmers participatory research. Attempts and achievements in the centralhigh lands of Ethiopia. In: Proceedings of client-o Research evaluation workshop, 16-18 October Holleta Agricultural Research Center, Holleta, Ethiopia.

[8] Habte E., Gebeyehu S., Tumsa S., Negash K., 2014. Decentralized common bean seed production and delivery system. Melkassa agricultural research center, Ethiopian institute of agricultural research, Ethiopia

[9] Legese Dady, 2004. Agricultural research and technology development in Ethiopia. Proceedings of the workshop held to discuss the socio-economic research results of 1998-2002. August 6-8, 2002, Addis Ababa, Ethiopia. EARO, 2004

[10] Misgana M., and Tadesse M.,2017. Performance evaluation of common bean (Phaseolus vulgaris (L.) varieties at Benatsemay Woreda of South Omo Zone, SNNPR, of Agriculture and Biosciences. P-ISSN: 2305-6622; E- ISSN: 2306-3599

Ethiopia. International Journal

[11] Rahmeto N.,2007. Determinants of adoption of improved haricot beans production package in Alaba Special Woreda, Southern Ethiopia. Haramaya University, Ethiopia.

[12] Netra H., HariM.,2019. Genetic variability, heritability and genetic advance ofCommon Bean (Phaseolus vulgaris L.) genotypes at mountain environment of Nepal. International Journal of Advanced Research in Biological Sciences ISSN: 2348-8069

[13] Porch T., James S., Daniel G., Scott J., James D., and Hannes D., 2013. Use of wild relatives and closely related species to adapt common bean to climate change, Agronomy, $\quad$ Vol. 3, No. 2, pp. 433461

[14] Semagn A., Walter D., Keith P., Donald H., Fentahun M.,2017. Participatory variety selection: A Tool to understand farmers' potato variety selection criteria. Open Agriculture. 2017; 2: 453-463

[15] Simon Yohannes, GobezeLoha, and Mesfin Kebede Gessese,2020. Performance

[16] Tadesse, D.,Medhin Z., and Ayalew A., 2014. Participatory on farm evaluation of improved maize varieties in Chilga district of north western Ethiopia. Int. J. Agric. For., 4: 402- 407. 
Participatory Varietal Selection and Agronomic Performance Evaluation of Common Bean (Phaseolus vulgaris L.) Genotypes in MetekelZone, North Western Part of Ethiopia

[17] Teame G., Ephrem S., and Getachew B., 2016. Performance evaluation ofcommon bean (Phaseolus vulgaris L.) varieties in Raya Valley, Northern Ethiopia. African Journal of Plant Science. Vol. 11(1), pp. 1-5, January 2017 DOI: 10.5897/AJPS2016.1464

[18] VSN International, 2012. Genstat for windows. 15th Edn., VSN International Ltd., UK

[19] YasinG., andMathewos A., 2017. Participatory approaches for varietalimprovement, it's significances and challenges in Ethiopia and some other countries: International Journal of Research Studies in Science, Engineering and Technology. Volume 4, Issue 1, 2017, PP25-40. ISSN 2349-4751

Citation: Zelalem Zewdu (2020). "Participatory Varietal Selection and Agronomic Performance Evaluation of Common Bean (Phaseolus vulgaris L.) Genotypes in MetekelZone, North Western Part of Ethiopia”., International Journal of Research Studies in Agricultural Sciences (IJRSAS), 6(6), pp. 11-16. DOI: http://dx.doi.org/10.20431/2454-6224.0606002

Copyright: (C) 2020Authors. This is an open-access article distributed under the terms of the Creative Commons Attribution License, which permits unrestricted use, distribution, and reproduction in any medium, provided the original author and source are credited. 